\title{
Use of External Indicators to Predict Maturity of Mini-watermelon Fruit
}

\author{
Edgar L. Vinson III' ${ }^{\mathbf{1}}$, Floyd M. Woods, and Joseph M. Kemble \\ Department of Horticulture, Auburn University, 101 Funchess Hall, Auburn \\ University, AL 36849
}

Penelope Perkins-Veazie

Horticultural Sciences, North Carolina State University, 600 Laureate Way, Suite 1329, Kannapolis, NC 28081

\author{
Angela Davis \\ USDA-ARS, 911 East Highway 3, Lane, OK 74555
}

\section{J. Raymond Kessler \\ Department of Horticulture, Auburn University, 101 Funchess Hall, Auburn University, AL 36849}

Additional index words. ground spot, senescent tendril, soluble solids, anthesis, ripeness

\begin{abstract}
Mini-watermelon [Citrullus lanatus (Thunb.)] cultivars Valdoria and Vanessa were evaluated at 20, 30, 40, or 50 days after anthesis to determine maturity at harvest. Fruit circumference, weight, ground spot color, and number of senescent tendrils were measured as external indicators for each watermelon. Soluble solids content (SS), pH, and SS:total acid ratio (SS:TA) of each watermelon were determined to provide an indication of internal maturity. Regression and Akaike Information Criterion fit statistics analyses were performed to determine significant relationships and best predictors for external indicators of internal maturity factors. In this study, external predictors were most closely linked to fruit $\mathrm{pH}$ rather than to SS or SS/TA. Of the external indicators tested, fruit weight, circumference, number of senescent tendrils, and International Commission on Illumination (CIE) $b^{*}$ color coordinate values of the ground spot were best related to fruit $\mathrm{pH}$. According to the regression models, two completely senesced tendrils, a circumference of $53 \mathrm{~cm}$, weight of $3 \mathrm{~kg}$, and CIE $b^{*}$ coordinate ground spot value of 40 are each sufficient to predict maturity when $\mathrm{pH}$ is used as the internal indicator of maturity under the conditions of this experiment.
\end{abstract}

In the United States, watermelon fruit quality is based on absence of external defects (odd shapes, sunburn, injury) and internal quality of high soluble solids (SS) (greater than 10\%), full pink to red color flesh, and crisp, non-mealy texture (U.S. Department of Agriculture, 2006). Watermelon fails to increase in sugars after being removed from the vine so it must be harvested near full ripeness (Rushing et al., 2001). Watermelon fruit have few external indicators of ripeness. Unlike tomatoes, there is no color break visible on watermelon rind, and the plethora of rind patterns and colors makes ripeness difficult to predict among genotypes and cultivars. Like tomatoes, using days after anthesis is an indicator, but not absolute predictor, of fruit maturity (Kano et al., 2008; Young et al., 1993). A number of subjective systems have been used by growers, including ground spot yellowness,

Received for publication 10 Feb. 2010. Accepted for publication 27 Apr. 2010.

This work was supported by the Alabama Fruit, Nut and Vegetable Industries and Alabama Agricultural Land Grant Alliance.

We acknowledge the technical assistance of Ms. Sheila Magby, Mr. Benjamin Blasius, Mr. Jason Burkett, Ms. Ashley Finney, and Mr. Scott Croxton for their assistance with harvesting and sample preparation.

${ }^{1}$ To whom reprint requests should be addressed; e-mailvinsoed@auburn.edu. senescent tendril next to the fruit pedicel, change in fruit wax (loss of shine), and thumping (dull sound when fruit are rapped with the knuckles) (Rushing et al., 2001). None of these harvest cues apply to all genotypes, because smaller types tend to sound different from larger types, and senescent tendrils may yield overripe watermelons for some. Introduction of near infrared spectroscopy (NIR) has been used in Japan and holds promise for screening watermelons after harvest, using SS content as the primary indicator of commercial acceptance (Jha and Mutsuoka, 2004). In the field, however, a relatively primitive system is used in the United States to select fruit for harvest. In this system, a cutter goes through the field and selects fruit considered to be ripe, which are then cut from the vine to be picked up by the harvest crew. The selection process is based partly on the attributes mentioned previously, by cutting fruit thought to be ripe to control internal color and sweetness, and by experience. There is a great need to find maturity indicators that can be integrated as technical aids during harvest for rapid, accurate selection of watermelon with acceptable SS content and color. Acoustic applications have been tried, but like with NIR, success is highly dependent on the cultivar and type (round versus oblong, seeded versus seedless) (Diezma-Iglesias et al., 2004; Stone et al., 1996).
Studies done on seeded, large (greater than $10 \mathrm{~kg}$ ) watermelons indicate that vine tendril proximal to the stem-end attachment may be the most useful indicator of maturity at harvest. A green non-wilted tendril indicates that maturity has not been attained (Mizuno and Pratt, 1973), whereas a wilted but not fully senescent tendril may indicate commercial maturity has been reached (Suslow, 2002). In other cultivars, tendril senescence may not provide a sharp delineation in maturity at harvest (Corey and Schlimme, 1988). Ground spot, the portion of the rind in contact with the soil, changes color over time and may be a useful indicator of watermelon maturity (Corey and Schlimme, 1988; Nip et al., 1968). Surface color expressed in terms of Hunter $\mathrm{a}^{*}$ or $\mathrm{b}^{*}$ coordinates have similarly been used to measure ground spot color. Hunter $\mathrm{a}^{*}$ coordinates measure variations in redness/greenness color and, therefore, chlorophyll metabolism. As chlorophyll content in watermelons decreases, carotenoids and anthocyanins (measured by Hunter $b^{*}$ coordinates or changes in yellowness/blueness) become more prominent (Goldschmidt, 2001). Notwithstanding, many cultivars have been developed with an array of colors and rind patterns, making ground spot color difficult to evaluate subjectively (Corey and Schlimme, 1988). Still other studies determined that rind gloss measurements calculated from Hunter $L$ values could lead to a nondestructive technique for determining watermelon maturity; however, rind gloss is cultivar-dependent as a result of differences in the quantity and structure of surface waxes (Corey and Schlimme, 1988). Finally, earlier studies suggest that fruit weight and diameter could potentially serve as indices of maturity; however, fruit size can be greatly influenced by factors such as plant density (Corey and Schlimme, 1988; Hassell et al., 2009; Nip et al., 1968). During the latter half of fruit development, sucrose accumulates (Motomura et al., 1989) as the number of enlarged cells increases (Kano, 2004). As internal cells enlarge, there is an increase in fruit weight and diameter. Sugars and organic acids accumulate in the heart and blossom end of watermelons as they advance toward maturity (Chisholm and Picha, 1986). The ratio of percent soluble solids and percent total acid (SS:TA) was correlated with watermelon quality (Elmstrom and Davis, 1981).

Mini-watermelons are usually seedless and are defined as weighing 2 to $4 \mathrm{~kg}$. Often, these watermelons have firm flesh, high SS, and high lycopene content (Perkins-Veazie et al., 2006). Although mini-watermelons have increased in popularity since their introduction in 2003 (Walter, 2009), little is known about the maturation process and external physical changes in the fruit offer few clues about its state of maturity. No studies have been done to determine the best external predictors of the internal quality in mini-watermelons. The objective of this study was to ascertain whether external indicators of maturity such as tendril senescence, ground spot color, watermelon circumference, and/or weight are reliable predictors of maturity in mini-watermelons. Internal 
maturity will be determined by measuring soluble solids, $\mathrm{SS}$ :TA ratio, or $\mathrm{pH}$.

\section{Materials and Methods}

Plant material and growth conditions. Four-week-old 'Vanessa' and 'Valdoria' triploid mini-watermelon transplants (Nunhems USA, Inc., Parma, ID) were set in $6 \mathrm{~m} \times 3-\mathrm{m}$ plots on 19 May 2006 and 20 May 2008 at the E.V. Smith Research Center in Shorter, AL (lat. $32^{\circ} 48^{\prime} \mathrm{N}$, long. $85^{\circ} 89^{\prime} \mathrm{E}$ ). Spacing of plants within a row was $0.5 \mathrm{~m}$. Both cultivars yield fruit of similar size and have a solid, dark green rind and red flesh. Four-week-old transplants of a pollenizer cultivar, Jenny (Nunhems USA, Inc.), were planted every third space within a row. Rows were formed on a Cahaba-Wickham-Bassfield sandy loam complex (fine, loamy, siliceous, thermic, Typic paleudult). Before planting, drip tape with an emitter spacing of $33 \mathrm{~cm}$ was installed and rows were subsequently covered with black plastic mulch. To collect sufficient fruit for analysis, female flowers were tagged at anthesis two to three times weekly from 14 June to 7 July 2006 and 19 June to 8 July 2008.

Fruit assessments. Mini-watermelons were harvested at 10-d intervals from 20 to $50 \mathrm{~d}$ after anthesis (DAA). Nine to 11 fruit were harvested per sampling date. Fruit weight, equatorial circumference, number of senescent tendrils (tendril proximal to the stem end of the watermelon and up to three tendrils formed before watermelon development), and ground spot color were recorded for each fruit at harvest. To remove variability in judgment about the state of the tendrils, only completely senesced tendrils were recorded. Ground spot color was measured in International Commission on Illumination L* $a^{*} b *($ CIELAB) color space coordinates using a Minolta CM-2002 Spectrophotometer with a CIE A standard illuminant (Minolta, Tokyo, Japan). The spectrophotometer was calibrated using a white calibration tile. One reading was taken from the center and edge of the ground spot and values were averaged. A transverse section was removed from the center of each fruit and heart tissue removed as cubes of $2 \mathrm{~cm} \times 2 \mathrm{~cm} \times 3$ $\mathrm{cm}$. Samples were placed in $18 \mathrm{~cm} \times 20-\mathrm{cm}$ freezer bags $0.05 \mathrm{~mL}$ thick with zipper closure and held at $-80{ }^{\circ} \mathrm{C}$ until analyzed.

To determine SS, a 10-g subsample was taken from each bag while frozen and placed in a ceramic mortar dish to which $10 \mathrm{~mL}$ of double-distilled water having an electrical conductivity of $18.2 \mathrm{M} \Omega / \mathrm{cm}^{2}$ obtained through a Millipore Direct- $Q^{\mathrm{TM}} 5$ filter system (Millipore Corp., Bedford, MA) was added. Samples were pulverized using a mortar and pestle, and $1 \mathrm{~mL}$ of juice was used to measure SS at room temperature using a Leica Mark II Abbe Refractometer (Kernco Instruments, El Paso, TX). The remaining portion of each sample homogenate was clarified by centrifugation at $15,000 g_{\mathrm{n}}$ at $4{ }^{\circ} \mathrm{C}$ for $20 \mathrm{~min}$ (Model J2-21; Beckman Centrifuge, San Antonio, TX). The supernatant was filtered through a double layer of Miracloth (Calbiochem, La Jolla, CA) and brought up to a final volume of $40 \mathrm{~mL}$ with purified water at a $\mathrm{pH}$ of 8.2. A 5-mL sample was removed from each sample and placed in 100-mL beakers. Each sample was brought up to $30 \mathrm{~mL}$ with purified water with $\mathrm{pH}$ and TA determined using an automated titrimeter (Metrohm Titrino Model 751 GPD and Metrohm Sample Changer; Metrohm Corp., Herisau, Switzerland) and software (Brinkmann Titrino Workcell 4.4 Software; Brinkmann Corp., Westbury, NY). The automatic titrimeter was housed in a Fisher Scientific refrigerated chromatography chamber maintained at $10{ }^{\circ} \mathrm{C}$ (Model Isotemp Laboratory Refrigerator; Fisher Scientific, Raleigh, NC). A $0.1 \mathrm{M}$ solution of $\mathrm{NaOH}$ was titrated to the end point of $\mathrm{pH} 8.1$ and the results were expressed as citric acid equivalent using the formula: $[(\mathrm{mL}$ $\mathrm{NaOH} \times 0.1 \mathrm{~N} \times 0.064 \mathrm{meq} \cdot \mathrm{g}^{-1}$ of juice $) \times$ 100]. SS:TA was calculated by dividing percent SS by percent TA.

Statistics. The experimental design was completely randomized with watermelon cultivar and days to harvest in a factorial treatment arrangement with year considered a random variable. A days from planting date to flower tagging variable was used as a covariate in the model. Data collected were analyzed using SAS Version 9.1.3 (SAS Institute, Inc., Cary, NC). Analysis of variance was performed using PROC MIXED. Where only main effects were significant, polynomial contrasts were used to determine trends over days to harvest and differences in watermelon cultivars were determined using the main effect F-test at $\alpha=$ 0.05 . Where the watermelon cultivar by days to harvest interaction was significant, polynomial contrasts and paired comparison contrast were used to test simple effects at $P=0.05$. Simple linear regressions relating SS:TA, $\mathrm{pH}$, and SS to tendril number, watermelon circumference and weight, and CIELAB coordinates were performed using PROC MIXED, and the model fits were determined using the Akaike Information Criterion (AIC) fit statistics.

\section{Results}

A significant interaction of cultivar and DAA was found for the variables SS:TA, $\mathrm{pH}$, fruit circumference, senescent tendril number, and ground spot CIE a* and $\mathrm{b}^{*}$ (Table 1). Trends were similar with increasing DAA during both seasons; however, the magnitude was different (data not shown). There was a quadratic change in SS:TA with increasing DAA with fruit reaching a maximum SS:TA at 40 DAA. The SS:TA increased by $363 \%$ and $1003 \%$ from 20 to 40 DAA and then decreased by $22 \%$ and $68 \%$ from 40 to 50 DAA for 'Valdoria' and 'Vanessa', respectively. No differences were found between 'Valdoria' and 'Vanessa' at 20,30, or 50 DAA. At 40 DAA, 'Vanessa' had a higher SS:TA than 'Valdoria'.

A linear increase in $\mathrm{pH}$ occurred with increasing DAA for 'Valdoria' and 'Vanessa' reaching a maximum value at $40 \mathrm{DAA}$. The $\mathrm{pH}$ increased by $22 \%$ and $20 \%$ from the lowest to highest values for 'Valdoria' and 'Vanessa', respectively. No differences in juice $\mathrm{pH}$ were found between 'Valdoria' and 'Vanessa' at 20 to 40 DAA levels; at 50 DAA, 'Vanessa' had a higher $\mathrm{pH}$ than 'Valdoria'.

Fruit circumference increased up to 40 DAA for both cultivars and held constant through 50 DAA for 'Valdoria' but continued to increase for 'Vanessa' (Table 1). Fruit circumference for 'Valdoria' and 'Vanessa' increased from the lowest to highest values by $114 \%$ and $28 \%$, respectively. From 40 to 50 DAA, fruit circumference for 'Vanessa' increased by $2 \%$, whereas fruit circumference for 'Valdoria' was constant. Fruit circumference of 'Vanessa' was significantly larger than that of 'Valdoria' at 20 DAA, but at 30 DAA and

Table 1. The effects of days after anthesis to harvest on external and internal indicators of fruit ripeness in mini-watermelons during summer of 2006 and 2008 at E.V. Smith Research Center, Shorter, AL.

\begin{tabular}{|c|c|c|c|c|c|c|c|c|}
\hline \multirow[b]{2}{*}{ Treatment $^{z}$} & \multirow{2}{*}{\multicolumn{2}{|c|}{ Cultivar }} & \multicolumn{6}{|c|}{ Days after anthesis } \\
\hline & & & 20 & & 30 & 40 & 50 & Sign. $^{y}$ \\
\hline \multirow[t]{2}{*}{$\overline{\mathrm{SS}: \mathrm{TA}^{\mathrm{x}}}$} & & oria & $161 \mathrm{NS}^{\mathrm{W}}$ & & $220 \mathrm{NS}$ & $740 \mathrm{~b}$ & $586 \mathrm{NS}$ & $\mathrm{Q}^{* * *}$ \\
\hline & & essa & 80 & & 347 & $897 \mathrm{a}$ & 287 & $\mathrm{Q}^{* *}$ \\
\hline \multirow[t]{2}{*}{$\mathrm{pH}$} & & oria & $5.5 \mathrm{NS}$ & & $5.9 \mathrm{NS}$ & $6.7 \mathrm{NS}$ & $6.1 \mathrm{~b}$ & $\mathrm{~L}^{* * *}$ \\
\hline & & essa & 5.4 & & 6.0 & 6.5 & $6.3 \mathrm{a}$ & $\mathrm{L}^{* *}$ \\
\hline \multirow[t]{2}{*}{ Circumference $(\mathrm{cm})$} & & oria & $28.5 \mathrm{~b}$ & & $55.4 \mathrm{NS}$ & $61 \mathrm{NS}$ & $61 \mathrm{NS}$ & $\mathrm{Q}^{* * *}$ \\
\hline & & essa & $46.5 \mathrm{a}$ & & 46.0 & 58.4 & 59.4 & $\mathrm{~L}^{* *}$ \\
\hline Senescent & & oria & $1 \mathrm{NS}$ & & $1 \mathrm{~b}$ & $3 \mathrm{NS}$ & 3 NS & $\mathrm{L} * * *$ \\
\hline tendril number & & essa & 0 & & $1 \mathrm{a}$ & 3 & 3 & $\mathrm{Q}^{* *}$ \\
\hline Ground spot & & oria & $-5.6 \mathrm{~b}$ & & $-4.9 \mathrm{a}$ & $0.3 \mathrm{NS}$ & $7.0 \mathrm{NS}$ & $\mathrm{Q}^{* *}$ \\
\hline CIELAB $a^{*}$ & & essa & $-3.04 \mathrm{a}$ & & $-2.4 b$ & 0.4 & 1.9 & NS \\
\hline Ground spot & & oria & $15.8 \mathrm{~b}$ & & $35.3 \mathrm{~b}$ & $37.3 \mathrm{NS}$ & $49.6 \mathrm{NS}$ & $\mathrm{L} * * *$ \\
\hline \multirow[t]{2}{*}{ CIELAB b* } & & essa & $39 \mathrm{a}$ & & $39.8 \mathrm{a}$ & 40.6 & 42.8 & NS \\
\hline & \multicolumn{5}{|c|}{ Days after anthesis } & \multicolumn{3}{|c|}{ Cultivar $^{\mathrm{u}}$} \\
\hline Treatment $^{\mathrm{v}}$ & 20 & 30 & 40 & 50 & Sign. & Valdoria & Vanessa & Sign. \\
\hline Soluble solids (\%) & 8.8 & 10.3 & 11.3 & 9.8 & $\mathrm{Q}^{* *}$ & $\mathrm{~N} / \mathrm{A}$ & N/A & $\overline{\mathrm{N} / \mathrm{A}}$ \\
\hline Fruit weight $(\mathrm{kg})$ & 2.1 & 2.7 & 3.8 & 3.8 & $\mathrm{~L} * * *$ & $3.3 \mathrm{a}^{\mathrm{y}}$ & $2.9 \mathrm{~b}$ & NS \\
\hline
\end{tabular}

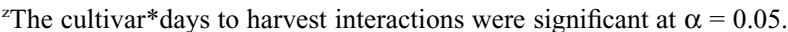

${ }^{y}$ Significant linear (L) or quadratic (Q) trend at $\alpha=* * 0.01$ or $* * * 0.001$.

xPercent soluble solids and percent total acid ratio.

${ }^{\text {w}}$ Difference between cultivars for each days to harvest were determined using single df paired contrasts at $\alpha=0.05$.

${ }^{\mathrm{v}}$ Only main effects significant at $\alpha=0.05$.

uDifference between cultivars were determined using main effect F-test at $\alpha=0.05$.

NS $=$ nonsignificant; N/A = not applicable. 
throughout the remainder of the study, circumference of the two cultivars did not differ statistically.

Senescent tendril number reached a maximum at 40 DAA and remained constant up to 50 DAA for 'Valdoria' and 'Vanessa' (Table 1). 'Valdoria' exhibited a linear trend and 'Vanessa' had a quadratic trend.

Ground spot CIE a* and $\mathrm{b}^{*}$ values increased by $225 \%$ and $214 \%$, respectively, with increasing DAA for 'Valdoria' (Table 1). No trends were evident for 'Vanessa', although CIE a* and $b^{*}$ values increased from 20 DAA to 50 DAA. Differences were found between varieties at 20 and 30 DAA for ground spot CIE a* and $b^{*}$. At 20 DAA and 30 DAA, ground spot CIE a* values for 'Valdoria' were more negative (and therefore more green) than 'Vanessa'. Ground spot $b^{*}$ values for 'Vanessa' were greater than for 'Valdoria' at 20 and 30 DAA.

No significant interactions of cultivar and DAA were measured in fruit weight or SS (Table 1). Fruit weight of 'Valdoria' was greater than that of 'Vanessa'. Watermelon weight increased linearly by $81 \%$ from 20 to 50 DAA with gains occurring between 20 and 40 DAA. SS increased quadratically with DAA, increasing $28 \%$ from 20 to 40 DAA. SS decreased $20 \%$ between 40 and 50 DAA.

According to $P$ values generated from regression analysis, linear relationships were found between the external predictors of ripeness and all the internal maturity indicators of fruit ripeness (Table 2). Linear relationships were found between external indicators senescent tendril number and fruit circumference and the internal maturity indicators, SS:TA, $\mathrm{pH}$, and SS, respectively. Linear relationships were also found between the fruit weight and $\mathrm{pH}$ and SS and between CIE $b^{*}$ and $\mathrm{pH}$. Based on AIC fit statistics, in which a smaller number indicates a better fit, senescent tendril number and fruit circumference and weight were better predictors of $\mathrm{pH}$ than they were of SS:TA or SS.

With $\mathrm{pH}$ as an internal ripeness indicator, predictions of maturity can be made with the selected external predictors using the following equation: $\mathrm{y}=(\mathrm{x} 1 \ldots \mathrm{xi})$, where $\mathrm{y}=$ internal indicator and $\mathrm{x}=$ predictor (Nip et al., 1968). A pH of 5.8 was found to indicate maturity in 'Xite', 'Valdoria', and 'Minipool' miniwatermelon cultivars (Perkins-Veazie et al., 2006). In Table 2 , the equation with one

Table 2. Regression equations relating external predictors to internal indicators of fruit ripeness in two mini-watermelon cultivars during the summer of 2006 and 2008 at E.V. Smith Research Center, Shorter, AL.

\begin{tabular}{lll}
\hline Regression equations & $\mathrm{AIC}^{\mathrm{z}}$ & $\operatorname{Pr}>\mathrm{F}$ \\
\hline${ }^{\mathrm{y}} \mathrm{SS}: \mathrm{TA}=1.89+1.0$ (senescent tendril number) & 507.4 & 0.001 \\
$\mathrm{pH}=5.5+0.25$ (senescent tendril number) & 168.7 & 0.001 \\
${ }^{\mathrm{x}} \mathrm{SS}=9.2+0.48$ (senescent tendril number) & 342.3 & 0.0001 \\
$\mathrm{SS}: \mathrm{TA}=0.72+0.13$ [circumference $(\mathrm{cm})]$ & 514.4 & 0.0461 \\
$\mathrm{pH}=5.1+0.04$ [circumference $(\mathrm{cm})]$ & 187.6 & 0.0001 \\
$\mathrm{SS}=9.0+0.05$ [circumference $(\mathrm{cm})]$ & 364.9 & 0.0198 \\
$\mathrm{pH}=4.8+0.04$ [weight $(\mathrm{kg})]$ & 159.2 & 0.0001 \\
$\mathrm{SS}=9+0.35$ [weight $(\mathrm{kg})]$ & 366.1 & 0.0029 \\
pH $=5.7+0.007$ (CIELAB b*) & 221.1 & 0.0309
\end{tabular}

${ }^{\mathrm{z}}$ Akaike Information Criterion (AIC) fit statistics. Smaller values indicate a better fit model.

yPercent soluble solids and percent total acid ratio.

${ }^{x}$ Soluble solids.

completely senesced tendril predicts a $\mathrm{pH}$ of $5.8( \pm 0.05)$ and two senesced tendrils predicts a $\mathrm{pH}$ of $6( \pm 0.05)$. A circumference of $46 \mathrm{~cm}$ predicts a $\mathrm{pH}$ of $5.9( \pm 0.15)$, whereas a circumference of $53 \mathrm{~cm}$ predicted a $\mathrm{pH}$ of 6 $( \pm 0.15)$. Ground spot CIE $b^{*}$ value between 30 and 40 predicts an internal $\mathrm{pH}$ of $5.9( \pm 0.3)$.

\section{Discussion}

Internal ripening values for each characteristic of both cultivars reached maxima at $\approx 40$ DAA (Table 1). Other indicators either declined or remained the same at 50 DAA. Dramatic increases in SS:TA were measured for both cultivars $(363 \%$ and $1003 \%$ for 'Valdoria' and 'Vanessa', respectively).

In this study, external ripening indicators were better predictors of $\mathrm{pH}$ than SS. SS represent all soluble components (sugars, acids, soluble polysaccharides), whereas $\mathrm{pH}$ is a more specific variable. Of the external criteria tested, fruit weight and circumference yielded the best correlations with $\mathrm{pH}$. However, in the field, counting senescent tendrils may be the most practical non-destructive approach to estimating watermelon ripeness. Ripening characteristics of mini-watermelon cultivars were similar to those of 'Jubilee', 'Crimson Sweet', and Ice Box type watermelons evaluated in other studies (Brown and Sumners, 1985; Corey and Schlimme, 1988; Elmstrom and Davis, 1981), which indicate that the predictors used to determine maturity in the present study could be applied broadly to other cultivars.

Ground spot color did not predict maturity to the same degree of accuracy as in other studies (Corey and Schlimme, 1988; Nip et al., 1968). There have been discrepancies concerning which method is the best way to measure ground spot, CIE a* or b*. Although ground spot color has been correlated with watermelon maturity, depending on the method of measure a predictive model will have to be developed and tested among genotypes and cultivars with a range of rind colors and patterns and among production environments.

Vine tendril proximal to the fruit stemend attachment has been used as an indicator of fruit maturity at harvest in other studies (Mizuno and Pratt, 1973; Suslow, 2002). It has been found that during the state of optimal harvest, the degree of tendril senescence varied and a wilted tendril did not consistently indicate maturity (Nip et al., 1968). In this study, the tendril in closest proximity to the watermelon and sequential tendrils (up to three) were allowed to become completely senesced. Whereas one senescent or senescing tendril may have been sufficient to predict maturity in other watermelon genotypes (Corey and Schlimme, 1988), mini-watermelons in the present study required two completely senescent tendrils before sufficient ripeness was achieved (Table 2). Moreover, in the case of mini-watermelons, when external predictors exceed what is necessary for the prediction of sufficient maturity, reductions in quality can result. Both 'Valdoria' and 'Vanessa', when harvested at 40 DAA, were characterized with "mealy" flesh and a slight orange coloration likely as a result of an increase in $\beta$-carotene, which is indicative of overripe watermelons. These conditions were substantially more pronounced in mini-watermelons harvested at 50 DAA.

Senescent tendril number, ground spot CIELAB b*, and watermelon circumference and weight successfully predicted maturity in 'Valdoria' and 'Vanessa' mini-watermelons in this study; however, growing conditions and cultural practices may alter these findings. Temperature, rainfall, and soil fertility may play a role in watermelon maturity and thus impact the stability of these external attributes as predictors of ripeness. Protected environments such as greenhouses or high tunnels have been used to extend growing seasons of various crops (Carey et al., 2009; Demchak, 2009; Lang, 2009; Wien, 2009). These specialized conditions can also have an impact on maturity. Moreover, factors such as geographical location, irrigation practices, and nitrogen fertilizer regimes can affect external traits such as watermelon fruit size distribution, fruit number, and vine length (Hassell et al., 2009: Smiljana et al., 2005). Internal qualities such as SS have been shown to increase linearly with increasing nitrogen fertilization (Smiljana et al., 2005). Vegetable grafting is a relatively new practice in the United States. Mini-watermelons grafted onto commercial rootstock have been shown to cause an increase in TA content as well as an increase in SS:TA ratio (Proietti et al., 2008) It is important to note that variations in rind colors and patterns exhibited among other watermelon types occur in mini-watermelons making development of a model to predict internal maturity using ground spot color more challenging.

\section{Conclusions}

Several external predictors could be used as a means of assessing optimal maturity at harvest for 'Valdoria' and 'Vanessa' miniwatermelons. Accordingly, the regression models indicate two completely senesced tendrils, a circumference of $53 \mathrm{~cm}$, weight of $3 \mathrm{~kg}$, and CIELAB b* coordinate ground spot value of 40 are each sufficient to predict optimal maturity at harvest for watermelons evaluated within the current study. A fruit SS of $10 \%$ and $\mathrm{pH}$ between 6 and 6.5 indicated 
ripeness in these watermelons. The degree to which external predictors assess maturity will depend on such factors as cultivar, location, and cultural practices used. Further studies are needed that involve more watermelon cultivars and varying cultural practices to test the accuracy of these external maturity predictors.

\section{Literature Cited}

Brown, A.C. and W.L. Sumners. 1985. Carbohydrate accumulation and color development in watermelon. J. Amer. Soc. Hort. Sci. 110:683687.

Carey, E.E., L. Jett, W.J. Lamont, Jr., T.T. Nennich, M.D. Orzolek, and K.A. Williams. 2009. Horticultural crop production in high tunnels in the United States: A snapshot. HortTechnology 19: 37-43.

Chisholm, D.N. and D.H. Picha. 1986. Distribution of sugars and organic acids within ripe watermelon fruit. HortScience 21:501-503.

Corey, K.A. and D.V. Schlimme. 1988. Relationship of rind gloss and ground spot color to flesh quality of watermelon fruits during maturation. Sci. Hort. 34:211-218.

Demchak, K. 2009. Small fruit production in high tunnels. HortTechnology 19:44-49.

Diezma-Iglesias, B., M. Ruiz-Altisent, and P. Barreiro. 2004. Detection of internal quality in seedless watermelon by acoustic impulse response. Biosystems Eng. 88:221-230.

Elmstrom, G.W. and P.L. Davis. 1981. Sugars in developing and mature fruits of several watermelon cultivars. J. Amer. Soc. Hort. Sci. 106: 330-333.

Goldschmidt, E.E. 2001. Chlorophyll decomposition in senescing leaves and ripening fruits:
Functional and evolutionary perspectives. Acta Hort. 553:331-335.

Hassell, R.L., J.R. Schultheis, W.R. Jester, S.M. Olson, and G.A. Miller. 2009. In-row distance in triploid watermelon cultivars affects yield and quality in diverse environments in the southeastern United States. HortTechnology 19:538545.

Jha, S.N. and T. Mutsuoka. 2004. Nondestructive determination of acid-Brix ratio of tomato juice using near infrared spectroscopy. Intl. J. Food Sci. Technol. 39:425-430.

Kano, Y. 2004. Effects of SADH treatment on cell size and types of sugars accumulated in melon fruits. J. Hort. Sci. Biotechnol. 79:14-17.

Kano, Y., I. Youichi, Y. Kanamori, and N. Fukuoka. 2008. Effects of night-heating of fruit on cell size and sucrose accumulation in the outer portion of watermelon (Citrullus lanatus Matsum. et Nakai). HortScience 43:792-794.

Lang, G.A. 2009. High tunnel tree fruit production: The final frontier? HortTechnology 19:50-55.

Mizuno, S. and H.K. Pratt. 1973. Relations of respiration and ethylene production to maturity in the watermelon. J. Amer. Soc. Hort. Sci. 98: 614-617.

Motomura, Y., K. Kanahama, and T. Saito. 1989. Accumulation and metabolism of sugars in melon fruits. J. Jpn. Soc. Hort. Sci. 58(suppl 2): 294-295.

Nip, W.K., E.E. Burns, and D.R. Paterson. 1968. Physical, chemical and organoleptic attributes of 'Charleston Gray' watermelons at different stages of maturity. Proc. Amer. Soc. Hort. Sci. 93:547-551.

Perkins-Veazie, P., J.K. Collins, D.J. Huber, and N. Maness. 2006. Ripening changes in minimelon fruit, p. 578-584. In: Holmes, G.J. (ed.). Proc. of
Cucurbitacea 2006. Universal Press, Raleigh, NC.

Proietti, S., Y. Rouphael, G. Colla, M. Cardarelli, M. De Agazio, M. Zacchinii, E. Rea, S. Moscatello, and A. Battistelli. 2008. Fruit quality of miniwatermelon as affected by grafting and irrigation regions. J. Sci. Food Agr. 88:1107-1114.

Rushing, J.W., J.M. Fonseca, and A.P. Keinath. 2001. Harvesting and postharvest handling, p. 156-164. In: Maynard, D.N. (ed.). Watermelons: Characteristics, production, and marketing. ASHS Press, Alexandria, VA.

Smiljana, G., S. Perica, G. Dumicic, L. Bucan, and N. Zanic. 2005. Growth and yield of watermelon on polyethylene mulch with different spacing and $\mathrm{N}$ ratio. HortScience 40:366-369.

Stone, M.L., P.R. Armstrong, X. Zhang, G.H. Brusewitz, and D.D. Chen. 1996. Watermelon maturity determination in the field using acoustic impulse impedance techniques. Trans. ASAE 39:2325-2330.

Suslow, T.V. 2002. Watermelon: Recommendations for maintaining postharvest quality. Nov. 2009. <http://postharvest.ucdavis.edu/Produce/ Producefacts/Fruit/watermelon.shtml $>$.

U.S. Department of Agriculture. 2006. United States standard for grades of watermelon. Mar. 2010. $<\mathrm{http}$ //www.ams.usda.gov/AMSv1.0/getfile? dDocName $=$ STELPRDC5050334 $>$.

Walter, S.A. 2009. Influence of plant density and cultivar on mini triploid watermelon yield and fruit quality. HortTechnology 19:53-57.

Wien, H.C. 2009. Floral crop production in high tunnels. HortTechnology 19:56-60.

Young, T.E., J.A. Juvik, and J.G. Sullivan. 1993. Accumulation of the components of total solids in ripening fruits of tomato. J. Amer. Soc. Hort. Sci. 118:286-292. 